\title{
Ecology Day
}

\author{
Maria Amélia Martins Loução $\mathbf{0}^{1,2}$ \\ ${ }^{1}$ Centre for Ecology, Evolution and Environmental Changes (cE3c), Faculdade de Ciências, Universidade de \\ Lisboa, 1749-016 Lisboa, Portugal \\ ${ }^{2}$ Sociedade Portuguesa de Ecologia - SPECO, Universidade de Lisboa, 1749-016 Lisboa, Portugal
}

Correspondence to: Maria Amélia Martins Loução (maloucao@fc.ul.pt)

Received: 3 July 2017 - Revised: 23 October 2017 - Accepted: 6 November 2017 - Published: 8 December 2017

The 150th anniversary of ecology was celebrated in 2016 with a round table discussion at the European Parliament, Brussels. There was an aspiration to develop a social collective mind of what ecology, as a science, represents in the present threatened world. The date, 14 September, was chosen because it was on that day Haeckel had published his "Ökologie und Chorologie" (Haeckel, 1866, II:286-289, reprinted in Acot 1998:II, 703-706) where he defined the term:

By ecology, we mean the whole science of the relations of the organism to the environment including, in the broad sense, all the "conditions of existence". These are partly organic, partly inorganic in nature; both are of the greatest significance for the form of organisms, for they force them to become adapted. Among the inorganic conditions, (...) we consider the physical and chemical properties of its habitat, the climate (light, warmth, atmospheric conditions of humidity and electricity), the inorganic nutrients, nature of the water and of the soil, etc. As organic conditions we consider the entire relations of the organism to all other organisms with which it comes into contact, and of which most contribute either to its advantage or its harm. Each organism has among the other organisms its friends and its enemies, those which favor its existence and those which harm it. The organisms which serve as organic foodstuff for others or which live upon them as parasites also belong in this category of organic conditions of existence. In a word, ecology is the study of all those complex interrelations referred to by Darwin as the conditions of the struggle for existence.
During the 20th century, ecology matured as a science and it was marked by different leading scientists. In 1935, Arthur Tansley published a paper (Tansley, 1935; translated by Stauffer 1957:140-141) where he defined the concept of ecosystem:

Though the organisms may claim our primary interest, when we are trying to think fundamentally we cannot separate them from their special environment, with which they form one physical system. These ecosystems, as we may call them, are of the most various kinds and sizes. They form one category of the multitudinous physical systems of the universe, which range from the universe as a whole down to the atom.

With this definition Tansley showed the relevance of studying interactions between organisms and of organisms with abiotic factors, as well as including man as an important asset in understanding ecosystem processes. Thus, with this new ecology unit he allowed the development of studies on ecosystems' evolution trends, using different time and spatial scales (Deléage, 1993). Henceforth, it was also possible to understand how organisms function as ecosystem engineers (Jones et al., 1996) and how humans play a major role in environmental change issues (Likens, 1993).

But the "age of ecology", as Worster (1994) called it, was influenced by Rachel Carson, Barry Commoner, Eugene Odum, Paul Ehrlich, and James Lovelock. While the first two published books pointed towards the negative role of humans in the environment, the others created scientific knowledge about ecological theories and how they could give scientific answers to environmental problems, effectively creating a bridge between science and society (Ehrlich and Ehrlich, 1990; Lovelock, 2000; Odum and Barret, 2005). After World War II, and with the public dissemination of those books, 
ecology became a political movement to fight environmental policies within society. Many other people, besides biologists and scientists, took part in this movement. But while some viewed humans as a force opposing nature, ecologists considered humans just as another animal species in nature. The science of ecology ends up defending the same values of protecting natural environment from destruction, but it uses scientific data to justify the options (Likens, 1993; Chapin III et al., 2002).

Costanza et al. (1997) estimated the value of ecosystem services raising the contribution of ecosystems and their evaluation to sustainable human well-being. This work had a broader impact on the scientific community with the development of numerous works, debates, and on-the-ground evaluations in different parts of the world. However, only in 2005 after the United Nations published the first Millennium Ecosystem Assessment did the notion of ecosystem destruction and its impact on global changes and human safety have a significant impact on society and politics (Rockström et al., 2009; de Groot et al., 2012; Costanza et al., 2014). Henceforth, the concept of human ecological footprint became a measure of human impact on our planet, and as a signa for the need to use a different approach to obtain prosperity based on well-being. The critical importance of ecosystem services challenges ecologists to establish an effective bridge between ecological and economical approaches (Costanza, 2012). This highlights the need for better measurements, good on-ground data, and new scientific approaches to develop more credible models adapted to today's society perceptions and problems (Carpenter et al., 2009).

Presently, ecologists are researchers that work in interdisciplinary teams to tackle the complexity of ecosystems and to provide predictable scenarios and operational solutions relevant for the sustainability of our world. In the present century, ecology is an integrative science that provides explanations about the challenges we face today that can reframe the relation between humans and nature. Today, the science of ecology is providing the knowledge necessary to reach the "sustainable development goals" of the United Nations.

Ecological data and knowledge can prove valuable in tackling economic challenges and health problems in order to create a more sustainable biosphere and a more equitable society based on a transdisciplinary paradigm. We need to reframe the definition of a scientist, an ecologist, who can work either with molecular biologists to understand the evolutionary histories of species in ecosystems or with microbiologists to convey the role of understudied microbes in the whole ecosystem functioning. Ecologists can go either to the sea to look for the trophic chains responsible for fish management and carbon sink or to the ice sheets to understand how the loss of function within those limiting ecosystems has a bigger impact on climate change. Ecologists contribute to filling the knowledge gap with regards to ecosystem complexities. For that they can also use both satellites and so- phisticated computer programs to model large environmental changes and predict further consequences.

Ecologists should also be able to communicate with citizens using a clear and simple, understandable scientific message. But they also need to show their endeavors, challenges, and breakthroughs for people to understand that science is not a tangible and immutable object that can be overcome without obstacles.

Following the political messages addressed last year in European Parliament during the 150th anniversary of ecology, the Portuguese Ecological Society (SPECO) proposed 14 September as the day to host different kinds of public and media events closely related to ecology, in a broad sense. This initiative is apparently not the first one. Other institutions all over the world are using different dates to celebrate "Ecology Day", sometimes combined with "ecological footprint" and focused on the relationship between humans and the environment.

We propose concentrating these diverse and sparse activities on this particular day, with a historic meaning, to give the opportunity to citizens of all ages to freely speak with ecologists, to develop practical workshops, to visit field experiments, particularly those in LTER (Long Term Ecological Research Network), to discuss basic and applied approaches, and to visit museums or exhibitions related to ecology. Dissemination of all these events is the core of our entire mission - which means reaching the media and different audiences. Together these activities will be launched on web pages and may constitute an umbrella of the different ecological societies all over the world, for those who want to participate. The great mission of this celebration should be to show ecology as a science to the public. Staying together within this mission we believe we could potentially convey the importance of ecology and ecosystem studies to people outside the scientific community, including policymakers and economists.

Competing interests. The authors declare that they have no conflict of interest.

Edited by: Jutta Stadler

Reviewed by: Roland Brandl and one anonymous referee

\section{References}

Carpenter, S. R., Mooney, H. A., Agard, J., Capistrano, D., DeFries, R. S., Díaz, S., Dietz, T., Duraiappah, A. K., Oteng-Yeboah, A., Pereira, H. M., Perrings, C., Reid, W. V., Sarukhan, J., Scholes, R. J., and Whyte, A.: Science for managing ecosystem services: Beyond the Millennium Ecosystem Assessment, P. Natl. Acad. Sci. USA, 106, 1305-1312, 2009.

Chapin III, F., Matson, P., and Mooney, H.: Principles of Terrestrial Ecosystem Ecology, Springer-Verlag, New York, USA, 2002. 
Costanza, R.: The value of natural and social capital in our current full world and in a sustainable and desirable future, in: Sustainability Science: The Emerging Paradigm and the Urban Environment, edited by: Weinstein, M., and Turner, R. E., Springer, 99-109, 2012.

Costanza, R., d'Arge, R., de Groot, R., Farber, S., Grasso, M., Hannon, B., Limburg, K., Naeem, S., O’Neil, R., Paruelo, J., Raskin, R., Sutton, P., and van den Belt, M.: The value of the world's ecosystem services and natural capital, Nature, 387, 253-260, 1997.

Costanza, R., de Groot, R., Sutton, P., van der Ploeg, S., Anderson, S. J., Kubiszewski, I., Farber, S., and Turner, R. K.: Changes in the global value of ecosystem services, Global Environ. Chang., 26, 152-158, https://doi.org/10.1016/j.gloenvcha.2014.04.002, 2014.

de Groot, R., Brander, L., van der Ploeg, S., Costanza, R., Bernard, F., Braat, L., Christie, M., Crossman, N., Ghermandi, A., Hein, L., Hussain, S., Kumar, P., McVittie, A., Portela, R., Rodriguez, L. C., ten Brink, P., and van Beukering, P.: Global estimates of the value of ecosystems and their services in monetary units, Ecosyst. Serv., 1, 50-61, https://doi.org/10.1016/j.ecoser.2012.07.005, 2012.

Deléage, J.-P.: História da Ecologia. Uma ciência do Homem e da Natureza, Nova Enciclopédia, Publicações Dom Quixote, Lisboa, 1993.

Ehrlich, P. and Ehrlich, A.: The population explosion, Simon and Schuster, 320 pp., 1990.
Haeckel, E.: Generelle Morphologie der Organismen, Reimer, Berlin, 1866.

Jones, C. G., Lawton, J. H., and Shachak, M.: Organisms as Ecosystem Engineers, in: Ecosystem Management: Selected Readings, edited by: Samson, F. B., and Knopf, F. L., Springer New York, New York, NY, 130-147, 1996.

Likens, G. E.: Human-accelerated environmental change-an ecologist's view, United States, Sponsor Org., 1993.

Lovelock, J.: A new look at life on Earth, 5th Edn., Oxford University Press, 2000.

Odum, E. and Barret, G. W.: Fundamentals of Ecology, 5th Edn., W. B. Saunders Company, Philadelphia and London, 2005.

Rockström, J., Steffen, W., Noone, K., Persson, Å., Chapin, F. S. I., Lambin, E., Lenton, T. M., Scheffer, M., Folke, C., Schellnhuber, H. J., Nykvist, B., de Wit, C. A., Hughes, T., van der Leeuw, S., Rodhe, H., Sörlin, S., Snyder, P. K., Costanza, R., Svedin, U., Falkenmark, M., Karlberg, L., Corell, R. W., Fabry, V. J., Hansen, J., Walker, B., Liverman, D., Richardson, K., Crutzen, P., and Foley, J.: A safe operating system for humanity, Nature, 461, 472-475, 2009.

Tansley, A.: The use and abuse of vegetational concepts and terms, Ecology, 16, 284-307, 1935.

Worster, D.: Nature's Economy: A history of ecological ideas, 2nd Edn., Cambridge University Press, 1994. 